\title{
Characterization of Rabbit lleal Receptors for Clostridium difficile Toxin A Evidence for a Receptor-coupled G Protein
}

\author{
Charalabos Pothoulakis, J. Thomas LaMont, Richard Eglow, Ning Gao, Jeffrey B. Rubins,* \\ Theoharis C. Theoharides, ${ }^{*}$ and Burton F. Dickey* \\ Section of Gastroenterology and the *Pulmonary Center, Evans Memorial Department of Clinical Research, Boston University School of \\ Medicine and the ${ }^{\ddagger}$ Department of Pharmacology, Tufts University School of Medicine, Boston, Massachusetts 02118
}

\begin{abstract}
The purpose of this study was to characterize the surface receptor for toxin A, the enterotoxin from Clostridium difficile, on rabbit intestinal brush borders (BB) and on rat basophilic leukemia (RBL) cells. Purified toxin $A$ was radiolabeled using a modified Bolton-Hunter method to sp act $2 \mu \mathrm{Ci} / \mu \mathrm{g}$, with retention of full biologic activity. ${ }^{3} \mathrm{H}$-Toxin $\mathrm{A}$ bound specifically to a single class of receptors on rabbit $B B$ and on $R B L$ cells with dissociation constants of $5.4 \times 10^{-8}$ and $3.5 \times 10^{-8} \mathrm{M}$, respectively. $R B L$ cells were highly sensitive to toxin $A$ (cell rounding) and had 180,000 specific binding sites per cell, whereas IMR-90 fibroblasts were far less sensitive to toxin $A$ and lacked detectable specific binding sites. Exposure of BB to trypsin or chymotrypsin significantly reduced ${ }^{3} \mathrm{H}$-toxin A specific binding. Preincubation of BB with Bandeirea simplicifolia (BS-1) lectin also reduced specific binding, and CHAPS-solubilized receptors could be immobilized with WGA-agarose. The addition of $100 \mathrm{nM}$ toxin $A$ accelerated the association of ${ }^{35}$ S-GTP $\gamma$ S with rabbit ileal BB, and preincubation of $B B$ with the GTP analogues GTPrS or Gpp(NH)p, significantly reduced ${ }^{3} \mathrm{H}$-toxin A specific binding. Our data indicate that the membrane receptor for toxin $A$ is a galactose and $\boldsymbol{N}$-acetyl-glucosamine-containing glycoprotein which appears to be coupled to a G protein. (J. Clin. Invest. 1991. 88:119-125.) Key words: Clostridium difficile toxins - enterotoxin - toxin receptor • membrane glycoprotein $\bullet \mathbf{G}$ protein
\end{abstract}

\section{Introduction}

Clostridium difficile, the causative agent of antibiotic-associated colitis in animals $(1,2)$ and humans $(3,4)$, produces two protein exotoxins: toxin A and toxin B. Toxin A is a $308-\mathrm{kD}$ (5) enterotoxin which elicits fluid secretion, acute inflammation, and increased permeability in rabbit ileum (6-8). A related $C$. difficile toxin, toxin $\mathrm{B}$, disaggregates actin microfilaments and causes rounding in cultured cells $(9,10)$, but possesses no en-

Presented in part at the 14th International Congress of Biochemistry, Prague, Czechoslavakia, June 1988, and the 88th Annual Meeting of the American Gastroenterological Association, New Orleans, LA, May 1988, and published in abstract form (1988. Gastroenterology. 94:A338).

Address correspondence to Charalabos Pothoulakis, M.D., Section of Gastroenterology, University Hospital, 88 E. Newton St., Boston, MA 02118.

Received for publication 1 February 1990 and in revised form 31 December 1990.

J. Clin. Invest.

(c) The American Society for Clinical Investigation, Inc.

0021-9738/91/07/0119/07 \$2.00

Volume 88, July 1991, 119-125 terotoxic activity in hamster or rabbit ileum $(6,7,11)$. In addition to its enterotoxic activity, toxin A possesses hemagglutinating activity against rabbit erythrocytes (12) and cytotoxic activity against several cultured cells $(13,14)$.

The mechanism of inflammatory enteritis and diarrhea associated with $C$. difficile toxin A appears to be quite complex. In addition to direct toxic effects on intestinal epithelial cells in Ussing chambers (15) and in culture (16), activating effects on inflammatory cells in the lamina propria may play an important role. For example, we have reported that toxin $\mathrm{A}$ induces chemotaxis and a pertussis toxin-sensitive cytosolic calcium transient in human neutrophils (17), and elicits a proliferative response in mouse spleen lymphocytes (18). These observations suggest that toxin $\mathrm{A}$ binding to membrane receptors on inflammatory cells activates signal transduction pathways which may exert cellular effects independent of the catalytic action of the toxin.

Until now, receptor-binding studies with toxin A have been limited because of the difficulty in preparing biologically active radiolabeled toxin A. Krivan et al. (12) presented indirect evidence that toxin $\mathrm{A}$ binds to hamster intestinal brush border (BB) ${ }^{1}$ and to rabbit erythrocyte ghosts using an enzyme-linked immunosorbent assay. Toxin A binding activity was significantly inhibited when erythrocyte and BB membranes were preincubated with alpha-galactosidase or with Bandeirea simplicifolia lectin, a plant lectin specific for alpha-linked galactose on glycoproteins and glycolipids. In a subsequent study Clark et al. (19) showed binding of ${ }^{125}$ I-toxin A to rabbit erythrocyte membrane glycolipids containing the sequence $\mathrm{Gal} \alpha 1-3 \mathrm{Gal} \beta 1$ 4GlcNAc. However, their radioiodinated toxin A preparation was only reported to possess hemagglutinating activity, thus preventing any speculation regarding pathophysiologic significance of binding.

The purpose of this study was to radiolabel toxin A with retention of biologic activity in order to characterize biologically relevant toxin A receptors in target cells. We report here that purified ${ }^{3} \mathrm{H}$-toxin A retains full cytotoxic and enterotoxic activities, and can be used to characterize specific $B B$ receptors for toxin A. We also report that the toxin A receptor appears to be coupled to a membrane $G$ protein(s). Finally, we describe a soluble binding assay which will allow purification of the toxin receptor.

\section{Methods}

\section{Materials}

Bolton-Hunter reagent ( $N$-succinimidyl $\left[2,3-{ }^{3} \mathrm{H}\right]$ propionate; $80 \mathrm{Ci} /$ $\mathrm{mmol}$ ) was obtained from Amersham International (Amersham, UK).

1. Abbreviations used in this paper: BB, brush border; CHAPS, 3-[3cholamidopropyl dimethylammoniol]-1-propanesulfonate; RBL, rat basophilic leukemia; WGA, wheat germ agglutinin. 
$\left.{ }^{35} \mathrm{~S}\right] \mathrm{GTP} \gamma \mathrm{S}(0.5 \mathrm{Ci} / \mathrm{mmol})$ was purchased from New England Nuclear (Boston, MA). Protein concentrations were determined with a protein assay kit (Bradford assay) from Bio-Rad Laboratories, Inc. (Richmond, CA) using BSA as a standard. Alkaline phosphatase activity in rabbit BB was measured colorimetrically with a kit from Sigma Diagnostics (St. Louis, MO). For enzymatic treatment of BB, elastase from swine pancreas, trypsin from bovine pancreas, alpha chymotrypsin from bovine pancreas, neuraminidase from Clostridium perfringens and betagalactosidase from Escherichia coli were purchased from Worthington Biochemicals (Freehold, NJ). Soybean trypsin-chymotrypsin inhibitor was obtained from Sigma Diagnostics and coffee bean alpha-galactosidase was obtained from Boehringer Mannheim Biochemicals (Indianapolis, IN). Bandeirea simplicifolia and Dolichos biflorus lectins were obtained from Sigma Diagnostics. The agarose-bound lectin wheat germ agglutinin (WGA) and concanavalin A (Con A) were obtained from E-Y Laboratories (San Mateo, CA). The zwitterionic detergent 3-[3-cholamidopropyl dimethylammoniol]-1-propanesulfonate (CHAPS) was purchased from Pierce Chemical Co. (Rockford, IL). Guanosine 5'-O-(3-thiotriphosphate) (GTP $\gamma \mathrm{S}$ ) was purchased from Boehringer Mannheim, and GTP, 5'-guanylyl imidodiphosphate $(\mathrm{Gpp}(\mathrm{NH}) \mathrm{p})$, and 5'-adenylyl imidodiphosphate (App(NH)p) were obtained from Sigma Diagnostics.

\section{Methods}

Toxin purification. Toxins A and B were prepared from culture supernatants of $C$. difficile strain 10463 . Toxin B was purified to homogeneity as described previously by us (10). Toxin A was purified by using a modification of the method of Sullivan et al. (11), as described by us (20). Enterotoxic activity was assayed in rabbit and mouse intestinal loops assay $(21,22)$. Typical stock solutions of purified toxin A used in these studies contained between 400 and $2,000 \mu \mathrm{g} / \mathrm{ml}$ protein as measured by Bradford's method (23) and were cytotoxic against RBL and fibroblasts at dilutions of $10^{4}$.

Radiolabeling of toxin A. Toxin A was ${ }^{3} \mathrm{H}$-labeled with the BoltonHunter reagent ( $N$-succinimidyl[2,3- $\left.{ }^{3} \mathrm{H}\right]$ propionate), exactly as described by Blomqvist et al. (24) for labeling staphylococcal alpha toxin. Unreacted Bolton-Hunter reagent was removed by dialysis against 50 $\mathrm{mM}$ Tris buffer ( $\mathrm{pH}$ 7.4). Radiolabeled toxin $\mathrm{A}$ was compared with unlabeled toxin A for cytotoxic activity (see below), for enterotoxic activity in rabbit and mouse ileal loops $(21,22)$, and by nondenaturing and SDS polyacrylamide gel electrophoresis according to Laemmli (25).

Cytotoxic effects of toxin A on rat basophilic leukemia (RBL) cells and IMR-90 fibroblasts. The cytotoxic effects of toxin A were evaluated against two cell lines: IMR-90 fetal human lung fibroblasts and RBL cells. RBL cells secrete histamine, serotonin, and other mediators of immediate hypersensitivity $(26,27)$ and closely resemble mucosal mast cells (28). RBL and IMR-90 fibroblasts were grown in Falcon 250-ml tissue culture flasks and seeded onto 96-well Costar tissue culture plates as described by us (29). After $24 \mathrm{~h}$ incubation for RBL cells and $4 \mathrm{~d}$ for IMR-90 cells, each well contained a confluent monolayer of $\sim 40,000$ cells in $0.2 \mathrm{ml}$ of medium.

${ }^{3} \mathrm{H}$-Toxin A binding to RBL and IMR-90 cell monolayers. Toxin A binding to RBL cells and IMR-90 fibroblasts was estimated in cell monolayers growing in 24-well Costar plates, $48 \mathrm{~h}$ after seeding for RBL cells and 5-6 d after seeding for IMR-90 cells (29). On the day of the experiment, medium was removed, cells were washed twice with 2 $\mathrm{ml}$ of PBS, and then covered with $0.2 \mathrm{ml}$ of Dulbecco's Eagle Medium supplemented with $10 \%$ FCS, penicillin, and streptomycin. Binding assays were performed by adding $65 \mathrm{ng}^{3} \mathrm{H}$-toxin $\mathrm{A}(\sim 190,000 \mathrm{dpm})$ to each well which contained $5 \times 10^{5} \mathrm{RBL}$ or IMR-90 cells in $0.2 \mathrm{ml}$ of medium. The final concentration of radiolabeled toxin A was $1.4 \mathrm{nM}$ Unlabeled toxin $A$ was added to achieve a final concentration of $10^{-9}$ to $10^{-6} \mathrm{M}$ and cells were incubated for $60 \mathrm{~min}$ (unless otherwise indicated). After incubation, medium was removed, the monolayers were washed twice with $2 \mathrm{ml}$ of PBS ( $\mathrm{pH} 7.4$ ), and adherent cells were then solubilized in buffer containing $10 \%$ SDS. Cell-associated radioactivity was estimated by liquid scintillation counting. Background radioactivity in cell-free wells incubated with ${ }^{3} \mathrm{H}$-toxin $\mathrm{A}$ under the same conditions was always subtracted. The apparent dissociation constant of binding $\left(K_{d}\right)$ and the maximum binding capacity (binding sites per cell) were calculated by Scatchard plot analysis using the weighted leastsquares-fit IBM computer program "Ligand" as described by Munson and Rodbard (30), in which nonspecific binding is treated as a fitted parameter from a weighed analysis of the binding data. When equilibrium binding of toxin $\mathrm{A}$ was measured at a single ligand concentration, as for the assessment of binding in the presence of lectins, specific binding of toxin A was determined by subtracting nonspecific binding (the amount of ${ }^{3} \mathrm{H}$-toxin $\mathrm{A}$ bound in the presence of excess unlabeled toxin A) from total binding (the amount of ${ }^{3} \mathrm{H}$-toxin $\mathrm{A}$ bound in the absence of unlabeled toxin $\mathrm{A}$ ).

Binding of ${ }^{3} \mathrm{H}$-toxin $\mathrm{A}$ to rabbit ileal brush borders. Rabbit BB were purified from 10-30-cm-long ileal segments by an EDTA-chelation method as described by Hopfer et al. (31), and stored at $-70^{\circ} \mathrm{C}$ in 50 $\mathrm{mM}$ Tris buffer ( $\mathrm{pH}$ 7.4) until use. The degree of purification of $\mathrm{BB}$ was estimated by determining alkaline phosphatase (32) and sucrase (33) activities and by light microscopy of homogenates and purified BB. In all BB preparations, alkaline phosphatase enrichment was greater than fivefold and sucrase enrichment greater than 12-fold in the purified BB.

$\mathrm{BB}$ binding experiments were performed in a total volume of $0.2 \mathrm{~m}$ of $50 \mathrm{mM}$ Tris buffer ( $\mathrm{pH} 7.4$ ) containing $0.1 \mathrm{mg}$ of purified BB. Experiments were carried out in 1.8-ml Eppendorf tubes precoated with 5\% skim milk in $0.2 \mathrm{M} \mathrm{NaCl}, 50 \mathrm{mM}$ Tris ( $\mathrm{pH} 7.4$ ) to reduce nonspecific binding of ${ }^{3} \mathrm{H}$-toxin $\mathrm{A}$ to the tube. After 5-120-min incubations, $1 \mathrm{ml}$ of Tris buffer at $4^{\circ} \mathrm{C}$ was added and tubes were centrifuged at $11,000 \mathrm{~g}$ for $3 \mathrm{~min}$. Pellets were rinsed two times with $1 \mathrm{ml}$ of Tris buffer then dissolved in $0.3 \mathrm{ml}$ of buffer containing $10 \%$ SDS and subjected to scintillation spectrometry. Specific binding was calculated as described above. Background radioactivity in tubes incubated with ${ }^{3} \mathrm{H}$-toxin $\mathrm{A}$ under the same conditions containing no membranes was always subtracted, and accounted for $\sim 1 \%$ of added radioactivity.

Effect of enzymes and lectins on ${ }^{3} H$-toxin $A$ binding to $B B$. Purified rabbit BB $(2 \mathrm{mg} / \mathrm{ml})$ were incubated at $37^{\circ} \mathrm{C}$ with $3 \%$ (wt/wt) of trypsin, chymotrypsin, neuraminidase, and elastase in $50 \mathrm{mM}$ Tris buffer (pH 7.4), or with $1.5 \mathrm{U}$ of coffee bean alpha-galactosidase (pH 6.0) or $2.5 \mathrm{U}$ of jack bean beta-galactosidase ( $\mathrm{pH} 4.0$ ). After incubation, BB were washed twice with Tris buffer ( $\mathrm{pH} 7.4)$ at $4^{\circ} \mathrm{C}$ to remove any residual enzyme. To prevent trypsin digestion of ${ }^{3} \mathrm{H}$-toxin A, soybean trypsin inhibitor was added $(2 \mu \mathrm{g} / \mathrm{ml})$ to the binding assays. Specific binding of ${ }^{3} \mathrm{H}$-toxin $\mathrm{A}$ to $100-\mu \mathrm{g}$ aliquots of $\mathrm{BB}$ at $4^{\circ} \mathrm{C}$ for $60 \mathrm{~min}$ was then assayed as described above.

In another series of experiments, purified rabbit BB $(0.1 \mathrm{mg} / \mathrm{ml})$ were preincubated with $25 \mu \mathrm{g} / \mathrm{ml}$ of either $B$. simplicifolia (BS-1) or with $D$. biflorus (DBA) lectins. BB were then washed twice with $1 \mathrm{ml}$ of buffer to remove unbound lectin and ${ }^{3} \mathrm{H}$-toxin $\mathrm{A}$ specific binding was then assayed at $22^{\circ} \mathrm{C}$ for $60 \mathrm{~min}$ to avoid cryoagglutination which occurs at lower temperatures.

Inhibition of ${ }^{3} \mathrm{H}$-toxin $\mathrm{A}$ binding by GTP analogues. Purified rabbit ileal BB (100 $\mu \mathrm{g} /$ tube) were preincubated with $100 \mu \mathrm{M} \mathrm{GTP}, \mathrm{GTP} \gamma \mathrm{S}$, $\mathrm{Gpp}(\mathrm{NH}) \mathrm{p}$, and $\mathrm{App}(\mathrm{NH}) \mathrm{p}$ for $15 \mathrm{~min}$ at $37^{\circ} \mathrm{C}$ in $50 \mathrm{mM}$ Tris buffer (pH 7.4) in a final volume of $0.2 \mathrm{ml}$. Tubes were then cooled to $22^{\circ} \mathrm{C}$ and specific ${ }^{3} \mathrm{H}$-toxin $\mathrm{A}$ binding at $60 \mathrm{~min}$ was assayed as described above.

${ }^{35} S-G T P \gamma S$ binding to $B B$. Binding reactions were carried out at $30^{\circ} \mathrm{C}$ in a final volume of $0.2 \mathrm{ml}$. The reaction buffer consisted of 25 mM Hepes (pH 8.0), 40 mM MgCl, 1 mM EDTA, 1 mM DTT, 200 $\mathrm{mM} \mathrm{NaCl}, 0.2 \%$ Lubrol, $2 \mu \mathrm{M}{ }^{35} \mathrm{~S}-\mathrm{GTP} \gamma \mathrm{S}$, and $30 \mu \mathrm{g} / \mathrm{ml}$ of purified toxin A. Reactions were started by the addition of $100 \mu \mathrm{g}$ of purified BB and terminated at the indicated times by the addition of $2 \mathrm{ml}$ of icecold wash buffer ( $20 \mathrm{mM}$ Tris- $\mathrm{HCl}$ [pH 8.0], $25 \mathrm{mM} \mathrm{MgCl}, 100 \mathrm{mM}$ $\mathrm{NaCl})$. Free nucleotide was separated from bound by rapid vacuum filtration through $0.45 \mu \mathrm{m}$ BA85 nitrocellulose filters (Schleicher \& Schuell, Keene, NH). Filters were washed five times in $2 \mathrm{ml}$ of wash buffer, dried, and dissolved in $15 \mathrm{ml}$ of scintillation fluid for counting of radioactivity. 
${ }^{3} H$-Toxin $A$ binding to solubilized $B B$ receptor immobilized on $W G A$-agarose. The toxin A receptor was solubilized by incubating rabbit BB $(2 \mathrm{mg} / \mathrm{ml})$ with various amounts of CHAPS in $10 \mathrm{mM}$ Tris buffer ( $\mathrm{pH}$ 7.4) for $45 \mathrm{~min}$ on ice. The mixture was then centrifuged at $100,000 \mathrm{~g}$ for $45 \mathrm{~min}$ at $4^{\circ} \mathrm{C}$. The supernatant containing the solubilized receptor was concentrated to $1 \mathrm{ml}$ using a PM-10 filter (Amicon) and then diluted 10 -fold to a final CHAPS concentration of $0.2 \%$. Protein concentration in the pellet was determined by Peterson's modification of the Lowry assay (34).

The binding of ${ }^{3} \mathrm{H}$-toxin $\mathrm{A}$ to solubilized receptor immobilized on lectin-agarose was measured by a modification of the method of Nexo et al. (35). WGA and Con A linked to agarose beads were washed and suspended in working buffer (10 mM Tris containing $0.2 \%$ CHAPS (pH 7.4) for WGA and $10 \mathrm{mM}$ Tris, $0.2 \%$ CHAPS (pH 7.4) for Con A containing also of $1 \mathrm{mM} \mathrm{MnCl}$ and $\mathrm{CaCl}_{2}$ to ensure binding with glycoproteins). Solubilized BB proteins $(60-70 \mu \mathrm{g}$ in $0.1 \mathrm{ml})$ were added to lectin-agarose ( $80 \mu \mathrm{g}$ in $0.2 \mathrm{ml}$ ) for a total volume of $0.3 \mathrm{ml}$ in glass tubes precoated with $1 \%$ BSA to reduce nonspecific binding. After $2 \mathrm{~h}$ incubation at $22^{\circ} \mathrm{C}, 5 \mathrm{ml}$ of ice-cold working buffer was added and the beads collected by centrifugation at $750 \mathrm{~g} \times 5 \mathrm{~min}$ at $22^{\circ} \mathrm{C}$. The pellet was resuspended in $0.2 \mathrm{ml}$ of the working buffers and was then incubated for $1 \mathrm{~h}$ at various temperatures, as indicated, with ${ }^{3} \mathrm{H}$-toxin $\mathrm{A}$ either with or without a 100 -fold excess of unlabeled ligand. Samples were then washed twice by the addition of $5 \mathrm{ml}$ of working buffer followed by centrifugation ( $750 \mathrm{~g}$ for $5 \mathrm{~min}$ ), and the bead-bound radioactivity was measured by scintillation counting. ${ }^{3} \mathrm{H}$-Toxin A specific binding was estimated as described above. Nonspecific binding of ligand to the glass tube and to the lectin-agarose beads was always subtracted.

\section{Results}

Biologic activities of purified toxin A. Toxin A was purified $\sim 95$-fold from broth culture supernatants of $C$. difficile by sequential ammonium sulfate precipitation ion exchange chromatography and high-performance molecular seive chromatography (not shown). The yield by cytotoxicity assay was $15.4 \%$. Exposure of RBL cells $(40,000$ cells $/ 0.2 \mathrm{ml}$ well) to purified toxin A (40 $\mathrm{ng}$ to $40 \mu \mathrm{g} / \mathrm{ml}$ ) caused dose-dependant rounding with a $50 \%$ rounding concentration at $1 \mathrm{~h}$ of $400 \mathrm{ng} / \mathrm{ml}$. In contrast, addition of up to $5 \mu \mathrm{g} / \mathrm{ml}$ of toxin A to the same number of IMR-90 fibroblasts failed to induce any rounding in $1 \mathrm{~h}$. Purified toxin A (5-20 $\mu \mathrm{g} /$ loop) caused a dose-dependent increase in fluid secretion in mouse ileal loops (not shown), whereas toxin B at comparable doses had no effect.

Radiolabeling and binding studies with ${ }^{3} \mathrm{H}$-toxin A. Purified toxin $\mathrm{A}$ was tritiated to a specific activity ranging from 0.2 to $2 \mu \mathrm{Ci} / \mu \mathrm{g} .{ }^{3} \mathrm{H}$-Toxin A migrated identically to native toxin $\mathrm{A}$ on HPLC (not shown) and SDS-PAGE (Fig. $1 A$ ), and nondenaturing gels (Fig. $1 B$ ). Biologic activity of ${ }^{3} \mathrm{H}$-toxin $\mathrm{A}$ at all specific activities against RBL cells and in rabbit and mouse ileal loop assays were identical to native toxin $A$.

We next measured binding of toxin A to RBL monolayers (Fig. 2). ${ }^{3} \mathrm{H}$-Toxin A binding to RBL cells was linear over a broad range of cell number $\left(8 \times 10^{4}\right.$ to $5 \times 10^{5}$ cells per well). ${ }^{3} \mathrm{H}$-Toxin $\mathrm{A}$ binding at $4{ }^{\circ} \mathrm{C}$ was maximal at 60 min after which time toxin A binding began to decline falling to $\sim 30 \%$ of the 1 -h levels after $2.5 \mathrm{~h}$ (data not shown). There was no additional decline in specific binding if cells were preincubated for $2 \mathrm{~h}$ at $4^{\circ} \mathrm{C}$ in the absence of toxin. After $3 \mathrm{~h}$ incubation of RBL cell monolayers with ${ }^{3} \mathrm{H}$-toxin $\mathrm{A}$ at $4^{\circ} \mathrm{C}$, there was no detachment of cells from the monolayers by light microscopy and unbound ${ }^{3} \mathrm{H}$-toxin A was capable of binding specifically and causing rounding to a second RBL cell monolayer. In addition, the

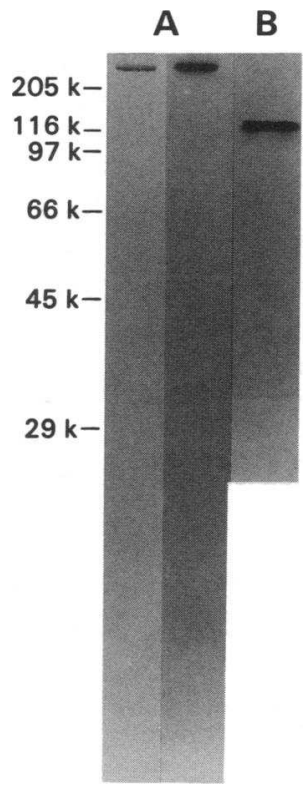

Figure 1. Gel electrophoresis of toxin A. Purified native toxin A $(10 \mu \mathrm{g} ; A$, left $)$ and ${ }^{3} \mathrm{H}$-toxin $\mathrm{A}(400 \mathrm{ng}, 200,000 \mathrm{dpm}$; $A$, right) were electrophoresed under identical conditions in the presence of SDS (Laemmli system). Both samples were incubated for $30 \mathrm{~min}$ with $5 \% 2$ mercaptoethanol and $1.25 \%$ SDS then heated to $100^{\circ} \mathrm{C}$ for $2 \mathrm{~min}$. Electrophoresis was performed on a $1.5 \mathrm{~mm}$ thick, $12 \%$ acrylamide gels at $50 \mathrm{~mA}$ for $2.5 \mathrm{~h}$. Arrows on left show the migration of molecular weight standards run simultaneously. (B) Nondenaturing PAGE of purified toxin $A(8 \mu \mathrm{g})$, at $25 \mathrm{~mA}$ for 18 $h$ at $4^{\circ} \mathrm{C}$ on a $6.5 \%$ gel.

electrophoretic mobility of ${ }^{3} \mathrm{H}$-toxin $\mathrm{A}$ incubated for $1 \mathrm{~h}$ with RBL cells was identical to ${ }^{3} \mathrm{H}$-toxin A not exposed to cells (not shown). These data indicated that the decline of ${ }^{3} \mathrm{H}$-toxin $\mathrm{A}$ binding to RBL cells after $1 \mathrm{~h}$ was not due to degradation of the toxin or to cell detachment, and was toxin dependent.

As shown in Fig. 2, binding of $1.4 \mathrm{nM}^{3} \mathrm{H}$-toxin A to RBL cells was inhibited $\sim 50 \%$ by an 80 -fold molar excess of unlabeled toxin $\mathrm{A}$, but not inhibited by a 100 -fold molar excess of toxin B. Heating of ${ }^{3} \mathrm{H}$-toxin $\mathrm{A}$ to $80^{\circ} \mathrm{C}$ for $10 \mathrm{~min}$ abolished cytotoxic and enterotoxic activity, as well as binding to RBL cells. We calculated an apparent $K_{\mathrm{d}}$ of $3.5 \times 10^{-8} \mathrm{M}$ and a $B_{\max }$

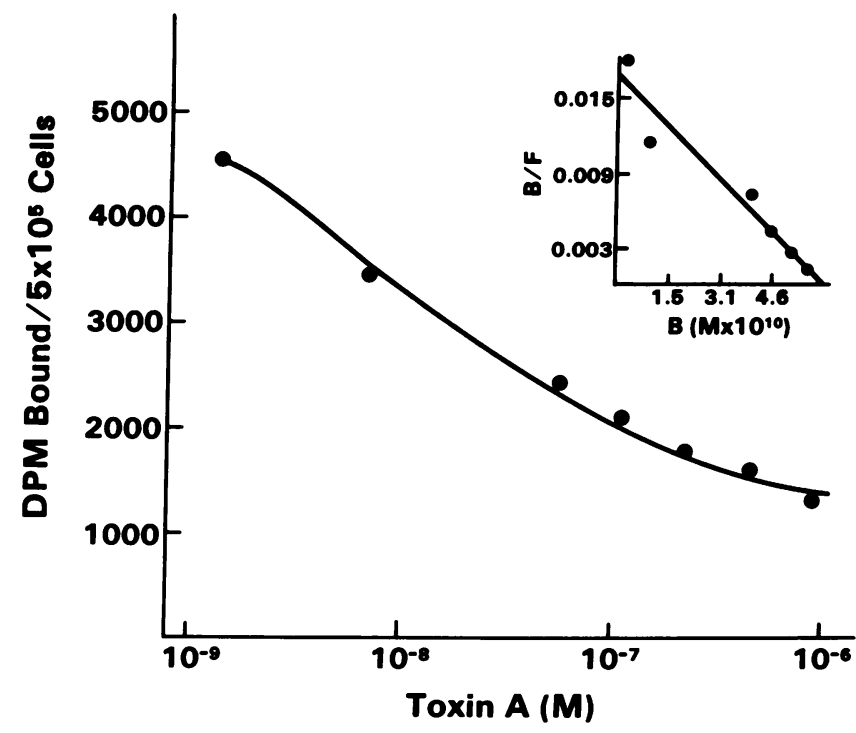

Figure 2. Competitive inhibition of ${ }^{3} \mathrm{H}$-toxin $\mathrm{A}$ binding to RBL cells by unlabeled toxin $A$. RBL cell monolayers $\left(5 \times 10^{5}\right.$ cells/well $)$ were incubated with $65 \mathrm{ng}{ }^{3} \mathrm{H}$-toxin $\mathrm{A}(190,000 \mathrm{dpm})$ and increasing doses of unlabeled toxin $\mathrm{A}$ for $60 \mathrm{~min}$ at $4^{\circ} \mathrm{C}$ in $0.2 \mathrm{ml}$ of complete medium ( $n=4$ for each group). The final concentration of ${ }^{3} \mathrm{H}$-toxin A was $1.4 \mathrm{nM}$. Specific binding was determined as described in Methods. (Inset) Scatchard plot for the data from the RBL cells. 
of 180,000 binding sites per RBL cell based on data from three separate experiments. Computer analysis of the binding data revealed the best fit to a linear Scatchard plot (Fig. 2 inset), suggesting the presence of a single class of receptors.

Binding of ${ }^{3} \mathrm{H}$-toxin $\mathrm{A}$ to $\mathrm{RBL}$ cells was strongly temperature dependent with $8 \mathrm{fmol} / 10^{6}$ cells bound at $4^{\circ} \mathrm{C}$ after $1 \mathrm{~h}$ but no specific binding at 22 and $37^{\circ} \mathrm{C}$. Rounding was not observed when RBL cells were exposed to toxin $A$ at $4^{\circ} \mathrm{C}$ for $1 \mathrm{~h}$ and maintained at that temperature for up to $24 \mathrm{~h}$. However, when cells were incubated with ${ }^{3} \mathrm{H}$-toxin $\mathrm{A}$ for $1 \mathrm{~h}$ at $4^{\circ} \mathrm{C}$, then washed thoroughly and incubated in toxin-free medium at $37^{\circ} \mathrm{C}$, rounding occured at $1 \mathrm{~h}$.

In view of the greater sensitivity of RBL cells than IMR-90 fibroblasts to the cytotoxic effects of toxin A, we compared binding of toxin A to RBL and IMR-90 cells in the presence or absence of a 150-fold excess of unlabeled toxin $A$ at $60 \mathrm{~min}$ at $4^{\circ} \mathrm{C}$. No specific ${ }^{3} \mathrm{H}-\mathrm{TxA}$ binding to IMR-90 cells was detectable at a ligand concentration of $1.4 \mathrm{nM}(130,000 \mathrm{dpm})$, whereas RBL cell monolayers bound specifically $5,570 \mathrm{dpm}$ $(11 \mathrm{fmol})$ per $10^{6}$ cells.

The next target examined was the rabbit ileum. We previously reported that instillation of $25 \mu \mathrm{g}$ toxin A into a $10-\mathrm{cm}$ rabbit ileal loop caused fluid secretion and an intense inflammatory response in $4 \mathrm{~h} \mathrm{(7).} \mathrm{We} \mathrm{therefore} \mathrm{instilled} 25 \mu \mathrm{g}$ of ${ }^{3} \mathrm{H}$-toxin $\mathrm{A}$ in rabbit ileal loops $(n=3)$ and observed identical histologic and secretory changes to those reported previously using unlabeled toxin $A(7,8)$. Binding of ${ }^{3} \mathrm{H}$-toxin A to rabbit ileal BB (Fig. 3) was similar to that observed for RBL cell monolayers. Scatchard plot analysis suggested the presence of one class of receptors (Fig. 3 inset) with a $K_{\mathrm{d}}$ of 5.4 $\times 10^{-8} \mathrm{M}$, and a maximum binding capacity of $5.9 \mathrm{pmol} / \mathrm{mg}$ $\mathrm{BB}$ protein. ${ }^{3} \mathrm{H}$-Toxin $\mathrm{A}$ binding to $\mathrm{BB}$ was also strongly temperature dependent with $0.7 \mathrm{pmol} / \mathrm{mg}$ of $\mathrm{BB}$ protein bound at

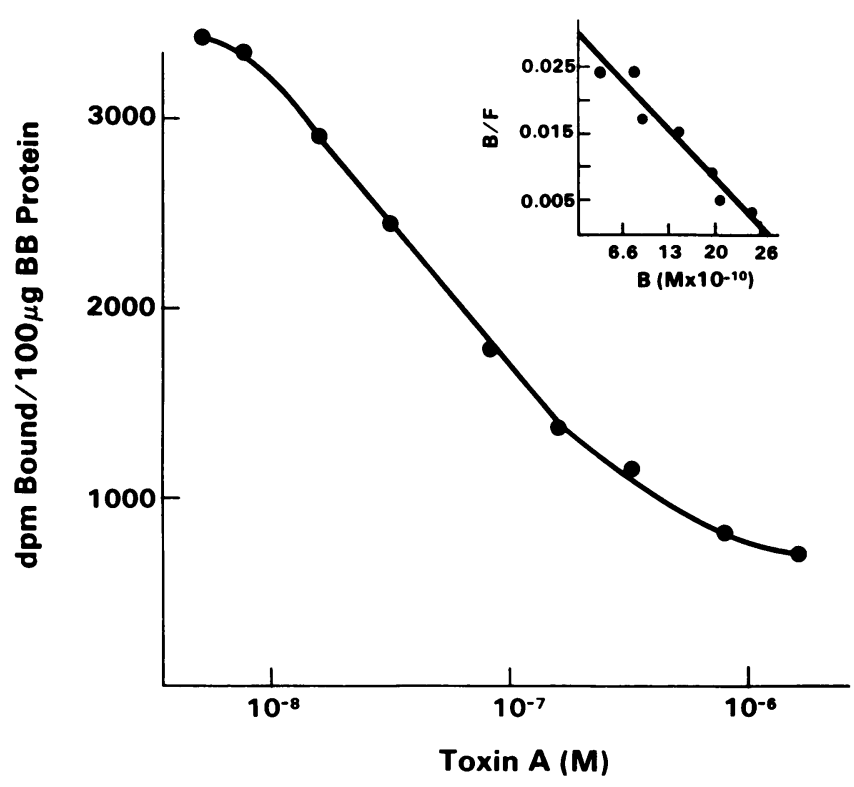

Figure 3. Competitive inhibition of ${ }^{3} \mathrm{H}$-toxin $\mathrm{A}$ binding to rabbit intestinal BB by unlabeled toxin A. Purified ileal BB $(100 \mu \mathrm{g})$ were incubated with $240 \mathrm{ng}{ }^{3} \mathrm{H}$-toxin $\mathrm{A}(110,000 \mathrm{dpm})$ for $60 \mathrm{~min}$ at $4^{\circ} \mathrm{C}$ in $0.2 \mathrm{ml} 50 \mathrm{mM}$ Tris buffer (pH 7.4) $(n=4$ for each group). Final concentration of ${ }^{3} \mathrm{H}$-toxin A was $5.3 \mathrm{nM}$. Specific binding was determined as described in Methods. (Inset) Scatchard plot. $4^{\circ}, 0.3 \mathrm{pmol} / \mathrm{mg} \mathrm{BB}$ protein bound at $22^{\circ} \mathrm{C}$ and no specific binding detectable at $37^{\circ} \mathrm{C}$. Binding of ${ }^{3} \mathrm{H}$-toxin $\mathrm{A}$ to $\mathrm{BB}$ was completely eliminated by heating the toxin to $80^{\circ} \mathrm{C}$ for $10 \mathrm{~min}$ and binding was unaffected by addition of a 100 -fold excess of toxin B to the membrane suspension.

Effects of enzymes and lectins on ${ }^{3} \mathrm{H}$-toxin $\mathrm{A}$ binding. We next tested the effects of several enzymes and lectins on ${ }^{3} \mathrm{H}$ toxin A binding to ileal BB. As shown in Table I, pretreatment of BB with trypsin or chymotrypsin significantly reduced ${ }^{3} \mathrm{H}$ toxin A binding by 52 and $87 \%$, respectively, whereas elastase and neuraminidase had no significant effect. Inhibition of binding was not due to inactivation of ${ }^{3} \mathrm{H}$-toxin $\mathrm{A}$ by the presence of residual enzyme, because residual enzyme activity was neutralized by the addition of trypsin-chymotrypsin inhibitor in the incubation buffer. In addition, preincubation of BB with alpha-galactosidase or BS-1 lectin, which binds to terminal alpha-linked galactose residues, significantly reduced ${ }^{3} \mathrm{H}$-toxin $\mathrm{A}$ specific binding by 52 and $58 \%$, respectively. Under the same conditions $D$. biflorus lectin, which preferentially binds to alpha-D-GalNAc, had no significant inhibitory effect, whereas beta-galactosidase significantly increased toxin A binding.

Effect of guanine nucleotides on ${ }^{3} \mathrm{H}$-toxin $\mathrm{A}$ binding to ileal $B B$. Nonhydrolyzable GTP analogues were used to inhibit toxin A binding by their well-described ability to dissociate signal transducing G-proteins from receptors, thereby resulting in a lower affinity state for ligands (36). ${ }^{3} \mathrm{H}$-Toxin A binding to $\mathrm{BB}$ receptors was strongly inhibited by $\mathrm{Gpp}(\mathrm{NH}) \mathrm{p}$ and $\mathrm{GTP} \gamma \mathrm{S}$ and to a lesser extend by GTP (Table II). A small inhibitory effect was caused by the ATP analogue App(NH)p.

Acceleration of ${ }^{35} S-G T P \gamma S$ binding to $B B$ membranes by toxin $A$. Kinetic binding of ${ }^{35} \mathrm{~S}-\mathrm{GTP}$ gamma $S$ to rabbit ileal $\mathrm{BB}$ was measured in the presence and absence of toxin A (Fig. 4). Toxin A resulted in a time-dependent increase in ${ }^{35} \mathrm{~S}-\mathrm{GTP} \gamma \mathrm{S}$ binding which was statistically significant at 5 and $10 \mathrm{~min}$ and remained higher than that obtained in the absence of toxin $A$ through $15 \mathrm{~min}$ of incubation. At $30 \mathrm{~min}$ the experimental values approached those of controls.

Table I. Effect of Enzyme and Lectin Treatment on ${ }^{3} \mathrm{H}$-Toxin $A$ Specific Binding to Intestinal BB

\begin{tabular}{lc}
\multicolumn{1}{c}{ Enzyme } & Percent binding \\
\hline None & 100 \\
Trypsin & $48^{*}$ \\
Chymotrypsin & $13^{\S}$ \\
Elastase & 105 \\
Neuraminidase & 84 \\
Alpha-galactosidase & $38^{\ddagger}$ \\
Beta-galactosidase & $164^{*}$ \\
BS-1 lectin & $42^{\ddagger}$ \\
DBA lectin & 94
\end{tabular}

Purified ileal BB $(2 \mathrm{mg} / \mathrm{ml})$ were incubated with $3 \%(\mathrm{wt} / \mathrm{wt})$ trypsin, chymotrypsin, elastase, or neuraminidase at $37^{\circ} \mathrm{C}$, or with $1.5 \mathrm{U}$ of alpha-galactosidase, $2.5 \mathrm{U}$ of beta-galactosidase, $25 \mu \mathrm{g} / \mathrm{ml} \mathrm{BS}-1$ lectin or DBA lectin at $22^{\circ}$ for $60 \mathrm{~min}$. After incubation, BB were washed two times with buffer at $4^{\circ} \mathrm{C}$ and ${ }^{3} \mathrm{H}$-toxin $\mathrm{A}$ binding to $0.1 \mathrm{mg}$ of BB was then determined as described in Methods. Statistical significance was analyzed by Student's $t$ test. ${ }^{*} P<0.02 ;{ }^{\ddagger} P<0.01 ;{ }^{\S} P<0.001$ vs. no treatment. 
Table II. Effect of Nucleotides on ${ }^{3} H$-Toxin A Binding to BB Membranes

\begin{tabular}{lc}
\hline Nucleotide $(100 \mu \mathrm{M})$ & Percent specific binding \\
\hline None & 100 \\
GTP $\gamma$ S & 49 \\
Gpp(NH)p & 26 \\
GTP & 71 \\
App(NH)p & 82 \\
\hline
\end{tabular}

Purified rabbit ileal BB membranes (100 $\mu \mathrm{g} /$ tube) were incubated with the nucleotides for $15 \mathrm{~min}$ at $37^{\circ} \mathrm{C}$. After incubation, ${ }^{3} \mathrm{H}$-toxin $\mathrm{A}$ specific binding was determined as described in Methods. Results represent the mean of three separate experiments, each with triplicate determinations.

Toxin A binding to solubilized BB receptor. Progressive solubilization of BB protein was achieved with increasing concentrations of CHAPS, reaching a maximum at $2 \%$ CHAPS with a CHAPS-to-protein (wt:wt) ratio of 10:1. Incubation of purified BB with $2 \%$ CHAPS for 45 min at $4^{\circ} \mathrm{C}$ resulted in the solubilization of $\sim 30 \%$ of BB membrane protein. $<10 \%$ of specific ${ }^{3} \mathrm{H}$-toxin $\mathrm{A}$ binding activity could be detected in BB membranes after extraction with $2 \%$ CHAPS, suggesting that nearly all toxin $\mathrm{A}$ binding sites had been solubilized.

Because our data (Table I) indicated that the toxin A BB receptor is a glycoprotein, we then determined whether the solubilized toxin A receptor could be adsorbed to lectin-agarose beads with retention of toxin binding activity. The CHAPS-solubilized BB receptor was premixed with either WGA-agarose or Con A-agarose as described in Methods to allow binding of the glycoprotein receptor to the beads. Our results showed that CHAPS-solubilized toxin A receptor that had been preadsorbed to WGA-agarose beads specifically bound $68,900 \mathrm{dpm}(0.42 \mathrm{pmol})$ at $4^{\circ} \mathrm{C}, 57,700 \mathrm{dpm}(0.35$ pmol) at $22^{\circ} \mathrm{C}$, and $31,500 \mathrm{dpm}(0.19 \mathrm{pmol})$ at $37^{\circ} \mathrm{C}$ of ${ }^{3} \mathrm{H}-$ toxin $\mathrm{A} / \mathrm{mg} \mathrm{BB}$ protein at $2.2 \mathrm{nM}$ total added ${ }^{3} \mathrm{H}$-toxin $\mathrm{A}$ $(70,000 \mathrm{dpm})$. Binding of ${ }^{3} \mathrm{H}$-toxin A was inhibited $~ 75 \%$ by a 100 -fold excess of unlabeled toxin A. Addition of albumin, ovalbumin, or IgG in a 100 -fold molar excess did not compete with ${ }^{3} \mathrm{H}$-toxin $\mathrm{A}$ binding to WGA-agarose containing the toxin A BB receptor. In contrast to WGA, no specific ${ }^{3} \mathrm{H}$-toxin A binding could be measured on Con A-agarose preincubated with solubilized BB membranes.

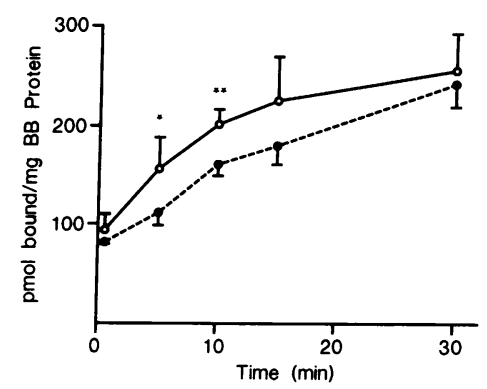

Figure 4. Binding of ${ }^{35} \mathrm{~S}-$ GTP $\gamma$ S to rabbit ileal BB. Purified ileal BB $(100 \mu \mathrm{g})$ were incubated with $2 \mu \mathrm{M}$ $\left[{ }^{35} \mathrm{~S}\right] \mathrm{GTP}$ gamma $\mathrm{S}$ at $30^{\circ} \mathrm{C}$ for the indicated times, in the presence (open circles) or absence (solid circles) of $30 \mu \mathrm{g} / \mathrm{ml}$ of toxin A. Results represent the mean \pm SD of four independent determinations. Statis-

tical significance was analyzed by Student's $t$ test. ${ }^{*} P<0.06{ }^{* *} P<$ 0.01 .

\section{Discussion}

We report for the first time the successful radiolabeling of purified toxin A of $C$. difficile with full retention of cytotoxic and enterotoxin activities. It is quite unlikely that the biologic activity of our ${ }^{3} \mathrm{H}$-toxin A preparations could be attributed to a population of unlabeled molecules because the stoichiometry of radiolabeling indicates that each molecule of toxin contained an average $0.7-7$ tritium atoms. In addition to retaining full biologic activity, ${ }^{3} \mathrm{H}$-toxin A migrated on PAGE with mobilities identical to native toxin, and with no evidence of any smaller peptides to suggest breakdown of toxin during the labeling procedure.

${ }^{3} \mathrm{H}$-Toxin A was used in our studies to demonstrate specific, moderately high affinity receptors on rabbit ileal $B B$ and $R B L$ cells. Several experiments support the likelihood that the receptor described here is physiologically relevant. Firstly, we were able to correlate ${ }^{3} \mathrm{H}$-toxin A binding on IMR-90 fibroblasts and RBL cells with cytotoxicity. Secondly, heat-inactivated radiolabeled toxin did not bind to cells and lacked cytotoxic or enterotoxic activity. Thirdly, ${ }^{3} \mathrm{H}$-toxin A which was bound to cells at $4^{\circ} \mathrm{C}$ exerted full cytotoxic activity when the cells were washed and warmed to $37^{\circ} \mathrm{C}$, indicating that binding at $4{ }^{\circ} \mathrm{C}$ is functional. Finally, in preliminary experiments we have observed that BS-1 lectin, an inhibitor of ${ }^{3} \mathrm{H}$-toxin A binding to BB membranes (Table I), significantly reduces the toxic effect of toxin A in rabbit small intestine (Eglow, R., and C. Pothoulakis, unpublished observations). In addition, Wilkins and Tucker (37) reported that BS-1 protected F9 cells monolayers, known to contain high levels of D-galactose residues, from the cytotoxic effects of toxin A.

In our studies as well as those of Krivan et al. (12), ${ }^{3} \mathrm{H}$-toxin A binding to ileal $\mathrm{BB}$ and $\mathrm{RBL}$ cells was higher at $4^{\circ} \mathrm{C}$ than at $22^{\circ} \mathrm{C}$, with no specific binding at $37^{\circ} \mathrm{C}$. A similar temperaturedependence in binding has been reported for other bacterial toxins. For example, Shigella toxin has been reported to bind maximally to rabbit jejunal microvillus membranes at $4^{\circ} \mathrm{C}$ (38). Diphtheria toxin (39) and tetanus toxin (40) bound tightly to target cells at $4^{\circ} \mathrm{C}$, but dissociated rapidly at $37^{\circ} \mathrm{C}$. The lack of detectable specific binding at higher temperatures may reflect more rapid dissociation of bound ligand at higher temperatures, because the toxin A receptor is only of moderately high affinity.

The results presented here confirm and extend the observations of Krivan et al. (12) who used an indirect method to study toxin A binding sites to hamster intestinal BB and rabbit erythrocyte membranes. They concluded that the toxin $\mathrm{A}$ binding site contained the oligosaccharide Gal $\alpha 1-3 \mathrm{Gal} \beta 1-4 \mathrm{GlcNAc}$. Our results (Table I) confirm the importance of galactose in ${ }^{3} \mathrm{H}$-toxin $\mathrm{A}$ binding. In addition, we were able to demonstrate specific binding of ${ }^{3} \mathrm{H}$-toxin $\mathrm{A}$ and to generate equilibrium binding parameters using Scatchard plot analyses. Krivan et al. were unable to show trypsin sensitivity of toxin A binding to hamster BB or rabbit erythrocytes, whereas we showed marked trypsin sensitivity of toxin A binding on rabbit BB (Table I). This discrepancy may result from a lower concentration of trypsin in their experiments $(0.25 \%)$ compared to ours $(3 \%)$.

Clark et al. (19) reported that ${ }^{125}$ I-toxin A bound primarily to red cell membrane glycolipids. Our experimental approach and results differ from those of Clark et al. in several important aspects. Firstly, our ${ }^{3} \mathrm{H}$-toxin A preparation retained full cytotoxic and enterotoxic activity compared to their ${ }^{125} \mathrm{I}$-toxin 
which retained only hemagglutinating activity. In our laboratory, attempts to radioiodinate toxin A resulted in loss of cytotoxic and enterotoxic activity (Pothoulakis, C., and J. T. LaMont, unpublished observations). It is not surprising that toxin A hemagglutinating activity binds to erythrocyte glycolipids, because many blood group antigens and probable lectin binding sites on erythrocytes are carried on glycolipids (41). Taken together, our results here and those of Clark et al. (19) suggest that toxin $\mathrm{A}$, a $308-\mathrm{kD}$ protein, possesses cytotoxic, enterotoxic, and hemagglutinating activity on the same molecule, and that these activities bind to glycoconjugates with a terminal trisaccharide Gal $\alpha 1-3 \mathrm{Gal} \beta 1-4 \mathrm{GlcNAc}$. The cytotoxic and enterotoxic activities of toxin $A$ are apparently mediated after binding to a membrane glycoprotein on BB and RBL cells, whereas the hemagglutinating activity is mediated by toxin binding to red cell membrane glycolipids.

The data presented in this study and in previous publications from our laboratory allow us to speculate on the mechanism of action of toxin A on diverse target cells. It appears that the effects of toxin A on target cells may be mediated either by receptor occupancy and activation of signal transduction pathways, or by receptor occupancy followed by internalization of the toxin and enzymatic modification of intracellular substrates. The first mechanism is best typified by neutrophils which possess high-density membrane receptors for ${ }^{3} \mathrm{H}$-toxin $\mathrm{A}$ (42). When exposed to toxin A these cells express an immediate pertussis toxin-sensitive calcium transient and exhibit chemotaxis (17). Another example of cellular activation by toxin $A$ occurs in mouse spleen lymphocytes which undergo proliferation when exposed to toxin $A$ and a calcium ionophore (18). In contrast to these activation events, exposure of intestinal epithelial cells to toxin $A$ in vivo $(6-8)$ and in vitro $(15,43)$, and exposure of cultured $T_{84}$ colon cancer cells to toxin A (16) results in cellular toxicity as manifested by necrosis, increased paracellular permeability, and inhibition of protein synthesis. Intestinal cell damage may result from specific enzymatic attack of the toxin on the actin-containing cytoskeleton $(15,16)$. It is unclear at present why some cells with a high density of ${ }^{3} \mathrm{H}$-toxin A receptors, such as neutrophils, have a low susceptibility to the cytotoxic effects of toxin $\mathrm{A}$, but we speculate that this resistance may be due to oxidative degradation of internalized toxin $\mathrm{A}$. We have observed toxin $\mathrm{A}$ inactivation during iodination, which is likely oxidatively mediated. We previously reported that $C$. difficile toxin $B$ is inactivated by normal neutrophils but not by chronic granulomatous disease neutrophils which lack the ability to generate oxygen radicals (44).

Our previous finding that toxin A elicits a pertussis toxinsensitive calcium transient in neutrophils (17) suggested that toxin $\mathbf{A}$ is capable of activating neutrophils via a signal transduction pathway which includes one of the $G_{i}$ species known to be present in neutrophil membranes (45). Our current finding (Fig. 4) that toxin A accelerates the association of ${ }^{35} \mathrm{~S}-\mathrm{GTP} \gamma \mathrm{S}$ with $\mathrm{BB}$ is consistent with this hypothesis, and the modulation of ${ }^{3} \mathrm{H}$-toxin A binding by guanine nucleotides (Table II) suggests that the toxin A receptor is coupled directly to a $G$ protein. Numerous other bacterial toxins $(46,47)$ and viral proteins (48) have also been found to bind to known physiologic cell surface receptors, or to activate cells by membrane receptor before being internalized and expressing enzymatic activity (49-51). Although it is possible that these phenomena reflect random association of toxins with any cell surface molecule, it seems more likely that teleologically these microbial proteins are exploiting the normal process of ligand binding followed by internalization to gain access to the interior of the cell. Further, it is possible that the ability of some toxins to activate cells via surface receptors reflects the evolutionary pressure to accelerate entry by triggering receptor internalization through mimicry of the conformational changes induced by native ligands. It remains to be determined whether the cell activation that occurs coincidentally with the internalization of toxins plays a role in the pathogenesis of disease.

\section{Acknowledgments}

We thank P. McAndrew, D. Desmond, and D. Skinner for expert technical assistance.

This study was supported by research grants AM 34583 and HL05503 from National Institutes of Health and National Research Service Award DK08395. Dr. Pothoulakis is an American Gastroenterological Association/Glaxo Scholar.

\section{References}

1. Abrams, G. D., M. Allo, G. D. Rifkin, R. Fekety, and J. Silva, Jr. 1980. Mucosal damage mediated by clostridial toxin in experimental clindamycin-associated colitis. Gut. 21:493-499.

2. Bartlett, J. G., A. B. Onderdonk, R. L. Cisneros, and D. L. Kasper. 1977. Clindamycin-associated colitis due to a toxin-producing species of Clostridium in hamsters. J. Infect. Dis. 136:701-705.

3. George, W. L., R. D. Rolfe, and S. M. Finegold. 1982. Clostridium difficile and its cytotoxin in feces of patients with antimicrobial agent associated diarrhea and miscellaneous conditions. J. Clin. Microbiol. 15:1049-1053.

4. Bartlett, J. G., W. Chang, M. Gurwith, S. L. Gorbach, and A. B. Onderdonk. 1978. Antibiotic-associated pseudomembranous colitis due to toxin-producing clostridia. N. Engl. J. Med. 298:531-534.

5. Dove, C. H., S.-Z. Wang, S. B. Price, C. J. Phelps, D. M. Lyerly, T. D. Wilkins, and J. L. Johnson. 1990. Molecular characterization of the Clostridium difficile toxin A gene. Infect. Immun. 58:480-488.

6. Mitchell, T. J., J. M. Ketley, S. C. Haslam, J. Stephen, D. W. Burdon, D. C. A. Candy, and R. Daniel. 1986. Effect of toxins A and B of Clostridium difficile on rabbit ileum and colon. Gut. 27:78-85.

7. Triadafilopoulos, G., C. Pothoulakis, M. J. O'Brien, and J. T. LaMont. 1987. Differential effects of Clostridium difficile toxins A and B on rabbit ileum. Gastroenterology. 93:273-279.

8. Triadafilopoulos, G., C. Pothoulakis, R. Weiss, C. Giampaolo, and J. T. LaMont. 1989. Comparative study of Clostridium difficile toxin A and cholera toxin in rabbit ileum. Gastroenterology. 97:1186-1192.

9. Wedel, N., P. Toselli, C. Pothoulakis, B. Faris, P. Oliver, C. Franzblau, and J. T. LaMont. 1983. Ultrastructural effects of Clostridium difficile toxin B on smooth muscle cells and fibroblasts. Exp. Cell. Res. 148:413-422.

10. Pothoulakis, C., L. M. Barone, R. Ely, B. Faris, M. E. Clark, C. Franzblau, and J. T. LaMont. 1986. Purification and properties of Clostridium difficile cytotoxin B. J. Biol. Chem. 261:1316-1321.

11. Sullivan, N. M., S. Pellet, and T. D. Wilkins. 1982. Purification and characterization of toxin A and B from Clostridium difficile. Infect Immun. 35:1032-1040

12. Krivan, H., C. F. Clark, D. F. Smith, and T. D. Wilkins. 1986. Cell surface binding site for Clostridium difficile enterotoxin: evidence for a glycoconjugate containing the sequence $\mathrm{Gal} \alpha 1-3 \mathrm{Gal} \beta-4 \mathrm{GlcNAc}$. Infect. Immun. 53:573-581.

13. Thelestam, M., and I. Florin. 1984. Cytopathogenic action of Closstridium difficile toxins. J. Toxicol. 3:139-180.

14. Rothman, S. W., M. K. Brown, A. Diecidue, and D. A. Foret. 1984. Differential effects of toxins A and B isolated from Clostridium difficile. Infect. Immun. 46:324-331.

15. Moore, R., C. Pothoulakis, J. T. LaMont, S. Carlson, and J. L. Madara. 1990. Clostridium difficile toxin A exerts neutrophil-independent effects on intestinal epithelial structure and function. Am. J. Physiol. 259(Gastrointest. Liver Physiol.):G165-G172.

16. Hecht, G., C. Pothoulakis, J. T. LaMont, and J. L. Madara. 1988. Clostridium difficile toxin A perturbs cytoskeletal structure and junction permeability in cultured human epithelial cells. J. Clin. Invest. 82:1516-1524.

17. Pothoulakis, C., R. Sullivan, D. A. Melnic, G. Triadafilopoulos, A. S. Gadenne, T. Meshulam, and J. T. LaMont. 1988. Clostridium difficile toxin A 
stimulates intracellular calcium release and chemotactic response in human granulocytes. J. Clin. Invest. 81:1741-1745.

18. Miller, P. D., C. Pothoulakis, T. R. Baeker, J. T. LaMont, and T. L. Rothstein. 1990. Macrophage-dependent stimulation of T cell depleted spleen cells by Clostridium difficile toxin A and calcium ionophore. Cell. Immun. 126:155-163.

19. Clark, G. F., H. C. Krivan, T. D. Wilkins, and D. F. Smith. 1987. Toxin A from Clostridium difficile binds to rabbit erythrocyte glycolipids with terminal Gal $\alpha$ 1-3Gal $\beta 1-4 G l c N A c$ sequences. Arch. Biochem. Biophys. 257:217-229.

20. Gilbert, R. J., G. Triadafilopoulos, C. Pothoulakis, C. Giampaolo, and J. T. LaMont. 1989. Effect of purified Clostridium difficile toxins on intestinal muscle. I. Toxin A. Am. J. Physiol. 256(Gastroint. Liver Physiol. 19):G759G766.

21. De, S. N., and D. N. Chatterge. 1953. An experimental study on the mechanism of action of Vibrio cholerae on the intestinal mucus membrane. $J$. Pathol. Bacteriol. 66:559-562.

22. Ohishi, I. 1983. Response of mouse intestinal loop to botulinum $\mathrm{C}_{2}$ toxin enterotoxin activity by cooperation of non-linked protein components. Infect. Immun. 40:691-695.

23. Bradford, M. 1979. A rapid and sensitive method for the quantitation of microgram quantities of protein utilizing the principle of protein dye binding. Anal. Biochem. 72:248-254.

24. Blomqvist, L., L. E. Appelgren, and M. Thelestam. 1987. Distribution of ${ }^{3} \mathrm{H}$-labelled staphylococcal alpha-toxin and a toxin fragment in mice. Infect. Im mun. 55:1906-1913.

25. Laemmli, U. K., 1970. Cleavage of structural proteins during the assembly of the head of bacteriophage $T_{4}$. Nature (Lond.). 227:680-685

26. Tamir, H., T. C. Theoharides, M. D. Gershon, and P. W. Askenase. 1982 Serotonin storage pools in basophil leukemia and mast cells: characterization of two types of serotonin binding protein and radioautographic analysis of the intracellular distribution of $\left[{ }^{3} \mathrm{H}\right]$ serotonin. J. Cell. Biol. 93:638-647.

27. Fewtrell, C., A. Kessler, and H. Metzger. 1979. Comparative aspects of secretion from tumor and normal mast cells. Adv. Inflamm. Res. 1:205-221.

28. Seldin, D. C., S. Adelman, K. F. Austen, R. L. Stevens, A. Hein, J. P Caulfield, and R. G. Woodbury. 1985. Homology of the rat basophil leukemia cell and rat mucosal mast cell. Proc. Natl. Acad. Sci. USA. 82:3871-3875.

29. Pothoulakis, C., G. Triadafilopoulos, M. Clark, C. Franzblau, and J. T. LaMont. 1986. Clostridium difficile cytotoxin inhibits protein synthesis in fibroblasts and intestinal mucosa. Gastroenterology. 91:1147-1153.

30. Munson, P. J. 1983. A computerized analysis of ligand binding data. Methods Enzymol. 92:543-576.

31. Hopfer, U., K. Nelson, J. Perrotto, and K. J. Isselbacher. 1973. Glucose transport in isolated brush border membrane from rat small intestine. J. Biol. Chem. 248:25-32.

32. Bessey, O. A., O. H. Lowry, and M. J. Brook. 1946. A method for the rapid determination of alkaline phosphatase with fire cubic millimeters of serum. $J$. Biol. Chem. 71:324-329.

33. Dahlquist, A. 1964. Method for assay of intestinal dissacharides. Anal. Biochem. 7:18-25.

34. Peterson, G. L. 1977. A simplification of the protein assay method of Lowry et al. which is more generally applicable. Anal. Biochem. 83:346-356.
35. Nexo, E., R. A. Hock, and M. D. Hollenberg. 1979. Lectin-agarose immobilization, a new method for detecting soluble membrane receptors. Application to studies with epidermal growth factor-urogastrone and transcobalamin-II. $J$. Biol. Chem. 254:8740-8743.

36. Gilman, A. G. 1987. G-proteins: transducers of receptor-generated signals. Annu. Rev. Biochem. 56:615-649.

37. Wilkins. T. D., and K. D. Tucker. 1989. Clostridium difficile toxin A (enterotoxin) uses $\mathrm{Gal} \alpha 1-3 \mathrm{Gal} \beta 1-4 \mathrm{GlcNAC}$ as a functional receptor. Microecol. Ther. 19:225-227

38. Mobassaleh, M., A. Donohue-Rolfe, M. Jacewicz, R. J. Grand, and G. T. Keusch. 1988. Pathogenesis of Shigella diarrhea: evidence for a developmentally regulated glycolipid receptor for Shigella toxin involved in the fluid secretory response of rabbit small intestine. J. Infect. Dis. 157:1023-1031.

39. Morris, R. E., A. S. Gerstein, P. F. Bonventre, and C. B. Saelinger. 1985. Receptor mediated entry of diphtheria toxin into monkey kidney (Vero) cells: electron microscopic evaluation. Infect. Immun. 50:721-727.

40. Critchley, D. R., P. G. Nelson, W. H. Habig and P. H. Fishman. 1985 Fate of tetanus toxin bound to the surface of primary neurons in culture: evidence for rapid internalization. J. Cell Biol. 100:1499-1507.

41. Basu, S., and M. Basu. 1982. Expression of glycosphingolipid glycosyltransferases in development and transformation. In The Glycoproteins. M. I. Horowitz, editor. Academic Press, Inc., New York. 265-285.

42. Becker, S. D., C. Pothoulakis, B. F. Dickey, and J. T. LaMont. 1989. Clostridium difficile toxin A binds to a G-protein coupled receptor on rabbit neutrophils. Gastroenterology. 96:A36. (Abstr.)

43. Eglow, R., C. Pothoulakis, J. C. O'Keane, and J. T. LaMont. 1990. Clostridium difficile toxin $\mathrm{A}$ inhibits protein synthesis in cultured cells and rabbit intestine. Gastroenterology. 98:A446. (Abstr.)

44. Ooi, W., H. G. Levine, J. T. LaMont, and R. A. Clark. 1984. Inactivation of Clostridium difficile cytotoxin by the neutrophil myeloperoxidase system. $J$. Infect. Dis. 149:215-219.

45. Goldsmith, P., P. Gierschick, G. Milligan, C. G. Unson, R. Vinitsky, H. L. Malech, and A. M. Spiegel. 1987. Antibodies directed against synthetic peptides distinguish between GTP-binding proteins in neutrophil and brain. J. Biol. Chem. 262:14683-14688.

46. Fraser, J. D. 1989. High affinity binding of staphylococcal enterotoxins A and B to HLA-DR. Nature (Lond.). 339:221-223.

47. Marrack, P., and J. Kappler. 1990. The staphylococcal enterotoxins and their relatives. Science (Wash. DC). 248:705-711.

48. Kornfeld, H., W. W. Cruikshank, S. W. Pyle, J. S. Berman, and D. M Center. 1988. Lymphocyte activation by HIV-1 envelope glycoprotein. Nature (Lond.). 335:445-448.

49. Stewart, S. J., V. Prpic, J. A. Johns, F. S. Powers, S. E. Graber, J. T. Forbes, and J. H. Exton. 1989. Bacterial toxins affect early events of T lymphocyte activation. J. Clin. Invest. 83:234-242.

50. Gray, L. S., K. S. Huber, M. C. Gray, E. L. Hewlett, and V. H. Engelhard 1989. Pertussis toxin effects on T lymphocytes are mediated through CD3 and not by pertussis toxin catalyzed modification of A G-protein. J. Immunol 142:1631-1638.

51. Rosoff, P. M., R. Walker, and L. Winberry. 1987. Pertussis toxin triggers rapid second messenger production in human $\mathrm{T}$ lymphocytes. J. Immunol. 139:2419-2423. 